\title{
Performance of Hybrid Solar Photovoltaic-Diesel Generator and Battery Storage Design for Rural Electrification in Malaysia
}

\author{
Amanda Halim ${ }^{1,2}$, Ahmad Fudholi ${ }^{1,3^{*}}$, Kamarulzzaman Sopian ${ }^{1}$, Stephen J. Phillips ${ }^{2}$ \\ ${ }^{1}$ Solar Energy Research Institute, Universiti Kebangsaan Malaysia, Bangi Selangor 43600, Malaysia \\ ${ }^{2}$ Optimal Power Solutions (M) Sdn Bhd, Petaling Jaya 46150, Malaysia \\ ${ }^{3}$ Research Centre for Electrical Power and Mechatronics, Indonesian Institute of Sciences (LIPI), Bandung 40135, Indonesia
}

Corresponding Author Email: a.fudholi@gmail.com

https://doi.org/10.18280/ijsdp.160509

Received: 14 May 2021

Accepted: 30 July 2021

\section{Keywords:}

hybrid energy system, rural electrification, solar radiation photovoltaic, diesel, configuration, feasibility, performance

\begin{abstract}
In recent years, the concept of hybrid energy systems (HESs) has been widely considered in the rural electrification of isolated or off-grid areas. Many cases have been studied since 2015, and the results indicate that an optimally designed HES is more reliable and economical than single energy source systems. Serving electricity to rural areas which are isolated from the central grid and thus suffer from lack of access requires an appropriate technology selection. In the provision of non-fluctuating electricity to a village on an island located in Mersing, Malaysia, solar energy is perceived to be the best addition to the existing power system that runs with a diesel generator as the main and single source. The area receives $4.46 \mathrm{kWhm}^{-2}$ of solar radiation per day on average having the hybrid photovoltaic-diesel-battery system set up to supply the energy demand from about 16 households with other public buildings. This paper discusses the feasibility of the proposed system design for rural electrification at $\mathrm{Kg}$ Teluk Berhala, Aur Island Mersing, Malaysia and its performance is analysed using HOMER Pro®. A comparative analysis against existing configuration (baseline) and hypothetical configuration was conducted in justifying the hybrid-PV-diesel-battery as the best option for this rural electrification.
\end{abstract}

\section{INTRODUCTION}

Driven by electricity demand, economic growth and new policies, the worldwide consumption of renewable energy (RE) increases by 3\% per year between 2018 and 2050 whilst that of petroleum and other liquids declines from $32 \%$ to $27 \%$ in 2050, as reported in the latest edition of International Energy Outlook 2019 by the U.S Energy Information Administration. On an absolute basis, liquid consumption increases in the industrial, commercial and transportation sectors and declines in the residential and electric sectors. Figure 1 taken from the report shows the graph of the primary energy consumption share by energy source recorded in 2018 and projected in 2050 [1].

Electricity plays an important role in the standard of living, economic growth and poverty alleviation [2]. In rural areas that have lack of access to electricity, communities suffer from cycle of poverty. Reliable energy access leads to improved socio-economic benefits, enables shops and businesses to prolong their operation hours, provides communities with excellent healthcare and allows children to study beyond school hours [3]. In their 2017 Energy Access Outlook, International Energy Agency (IEA) reported that approximately 1.1 billion people, or $14 \%$ of the global population, did not have access to electricity. Around $84 \%$ of those without electricity access reside in rural areas, and more than $94 \%$ are from Sub-Saharan and developing Asian countries [4]. According to 2019Tracking SDG7: The Energy Progress Report reported that the global electrification rate climbed from $83 \%$ to $89 \%$; this rate equated to a drop in the number of people without electricity access from 1.1 billion to about 840 million people $[5,6]$. Extensive electrification efforts have been exerted and relevant plans are currently being drafted or executed around the world. Current electrification efforts involve isolated areas such as rural places and islands where national utility grid connections are unavailable. In 1982, Cecelsky in and Glatt introduced the concept of rural electrification and explained it as "the role of rural in development" [7]. In 2014, Hirmer and Cruickshank tackled rural electrification on the basis of user values from different models and theories concept [8]. Zommer, in his study of the challenges of rural electrification, presented the typical features of industrial/urban and rural supply areas. The comparison of these features is summarized in Table 1 [9].

Relative to urban areas, rural villages face considerable limitations in term of electricity supply plans. These limitations include their difficult terrain, low population densities, low economic activity and lower power consumption. In this context, the extension of nationality utility grids to rural areas tends to be expensive and challenging. Providing power to rural communities, which are far from grid and suffer from lack of energy access, in a sustainable manner, requires the adoption of appropriate technology [10].

Off-grid Hybrid Renewable Energy Systems (HRESs), which are eco-friendly and cost-effective, are becoming known as an effective option for rural areas with poor grid power availability [11]. In recent years, the concept of HES 
has drawn increasing attention in the electrification of isolated or energy-deficient areas. Optimally designed HES' have been proved to be more reliable and economical than a single energy source system.

An off-grid HRES system is an electrical power generation system consisting of two or more energy sources which may be a combination of two or more RE sources or at least one renewable source and a conventional source. A common combination is that of Photovoltaic (PV) solar energy running in parallel or back-to-back with Diesel Generator (DG). As solar energy is known for its numerous advantages, including its inexhaustible and non-polluting properties, it is the most prominent source of RE. In providing non-fluctuating power supply, hybrid system often incorporate storage devices, such as batteries fuel cells [12-14].

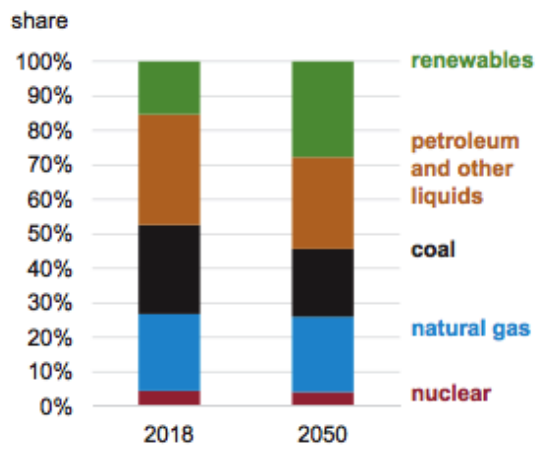

Figure 1. Primary energy consumption share in 2018 and 2050

Table 1. Typical features of industrial and rural supply areas

\begin{tabular}{|c|c|c|}
\hline Features & Industrial/Urban supply Areas & Rural Supply Areas \\
\hline Area load density $(\mathrm{kW} / \mathrm{km} 2)$ & 500 to 100,000 & 2 to 50 \\
\hline Consumer density (conn/km2) & $>500$ & 1 to 75 \\
\hline Number of consumers per km & & \\
\hline $\begin{array}{c}\text { line length (Both MV and LV } \\
\text { included) }\end{array}$ & $>75$ & 1 to 75 \\
\hline $\begin{array}{l}\text { Consumption density } \\
\left(\mathrm{kWh} / \mathrm{km}^{2}\right)\end{array}$ & $>2,000,000$ & 5,000 to 200,000 \\
\hline Total cost/kWh (US $\phi)$ & 10 to 15 & $\begin{array}{c}\text { Grid-based: } 12 \text { to } 50 \\
\text { Diesel-based: } 25 \text { to } 100 \text { or more PV home systems-based: } \\
50 \text { to } 500\end{array}$ \\
\hline $\begin{array}{l}\text { Investment costs per } \\
\text { connection (US\$), excluding } \\
\text { generation and transmission }\end{array}$ & $<500$ & 500 to 7000 , average 1200 , extremes of over 100,000 \\
\hline Social aspects & Limited & Specific financial support and solutions needed \\
\hline $\begin{array}{c}\text { Technical/ organisational } \\
\text { aspects }\end{array}$ & $\begin{array}{l}\text { Large projects; often heavy power } \\
\text { technologies on supply and demand side; } \\
\text { reasonable load factors as a result of mixed } \\
\text { loads }\end{array}$ & $\begin{array}{c}\text { Various technologies and small-scale applications; low } \\
\text { load factor because of dominant domestic and agricultural } \\
\text { loads; intensive customer support needed; ratio of labour } \\
\text { to capital high }\end{array}$ \\
\hline Socio-cultural aspect & Seldom of importance & Important \\
\hline Economic aspects & Profitable business opportunities & Limited profitable business opportunities \\
\hline
\end{tabular}

\section{HYBRID SOLAR SYSTEM FOR RURAL AREAS}

Based on the observation and findings from numerous of studies, researches as well as project implementation of solar power system, the complete replacement of DG with the RE sources for rural/remote areas is perceived to be impractical in a way that the RE sources are unstable $[15,16]$ According to the state of electricity access report by World Bank in 2017 disclosed that from a technological standpoint, the drawback with RE-based system resides in the intermittent nature of these sources due to weather conditions, hence has also suggested that hybrid system using RE sources together with batteries or a DG can be used to overcome the intermittency issues [17] Therefore the combination of RE sources with conventional sources would make a suitable solution to provide the finest of each product. Up to this moment when this article is being written, it is concluded that hybrid-PVdiesel system was recommended in most studies. [16, 18-21].

Previous studies have discussed on the system optimization using various tools such as HOMER and other several methods including the Particle Swarm Optimization (PSO), artificial neutral networks (ANN) and differential evaluation (DE) for sizing and operating strategies assessment for different system configuration [22-28]. Mahmoud and Ibrik in their study conducted in Palestine, suggested that utilizing PV-diesel hybrid system in remote areas is more economically feasible than standalone DG or grid extension [29] Some other studies presented the evaluation on the techno-economic feasibility and potential of different hybrid system configuration utilized in remote areas [30-34]. A study on PV-diesel hybrid power system with battery for a village in Saudi Arabia was performed and it was indicated that the proposed hybrid system appears to be more favorable, mainly when the fuel price is increased [35]. A study conducted in ref. [36] looking at the overall global potential for solar-battery mini grids for rural electrification and derived a comparative analysis of the respective regions using the Geographical Information System (GIS) software. The result shows that the utilization of hybrid PV-diesel configuration gives lower Levelised Cost of Energy (LCOE) than standalone DG in many regions.

In view of the facts obtained from the literature above, hybrid RE system was considered a promising technology and has a very high potential to reduce environmental pollution, and improve system stability while at the same time reducing the overall system cost. This paper discusses the design of the hybrid PV-diesel-battery system which has been selected to power up a village on an Island in Mersing. This involves the collection of the load consumption, RE source and component sizing of the system. HOMER Pro ${ }^{\circledR}$ has been extensively used in system modelling and analyzing the performance of the 
system based on the technical, economic and environmental aspects.

\section{SITE SPECIFICATION}

The project site named $\mathrm{Kg}$ Teluk Berhala is located on a island of Aur Island (Pulau Aur) exact coordination of $2^{\circ} 27^{\prime}$ 51.66" N: $104^{\circ} 30^{\prime} 15.83^{\prime \prime} \mathrm{E}$, The Aur Island is an island in Mersing District of Johor. It lies about 76 kilometers east of Mersing Town and is a part of the Johor Marine Park. Along with other 10 villages, $\mathrm{Kg}$ Teluk Berhala is the main village at Aur Island with a population recorded nearly to a hundred (100) people and the population is spread along the coastline in small settlements of four to six numbers of building including houses, school, police station, village hall (balai raya) and a small mosque (surau). Figure 2 shows the map view of the location which requires about two and half hours boat ride from Mersing Jetty to Pulau Aur during normal season.

This paper was prepared based on the plan initiated by the Tenaga National Berhad-Energy Services (TNBES), to refurbish the existing Solar Hybrid Station (SHS) installed at one of the villages on Aur Island. Kg Teluk Berhala does not have access to national main grid power and has been fully- served by DG system before the existing system was tested and commissioned in 2006. The refurbishment plan is mainly to revive the existing system which was no longer in operation due to component dysfunction as the time goes by. This includes the component and system upgrade works with updated configuration and latest technologies available. The site survey has been conducted to collect information of the existing components.

Table 2. Status and capacity of the existing component

\begin{tabular}{|c|c|c|c|}
\hline Component & Capacity & Unit & Status \\
\hline PV & 10 & $\mathrm{kWp}$ & Working \\
\hline Battery & 311 & $\mathrm{kWh}$ & Not Working \\
\hline $\begin{array}{c}\text { Diesel } \\
\text { Generator }\end{array}$ & 60 & $\mathrm{kVA}$ & Working \\
\hline Inverter (HPC) & 45 & $\mathrm{~kW}$ & Not Working \\
\hline ACDB & 125 & $\mathrm{~A}$ & Working \\
\hline System Voltage & & 24 & \\
\hline
\end{tabular}

As per identified from the site survey output and tabulated in Table 2, the system was not fully in operation and the loads were solely fed by the DG. Therefore, this system is considered as a newly built system from the updated design based on the current estimation on the load consumption.

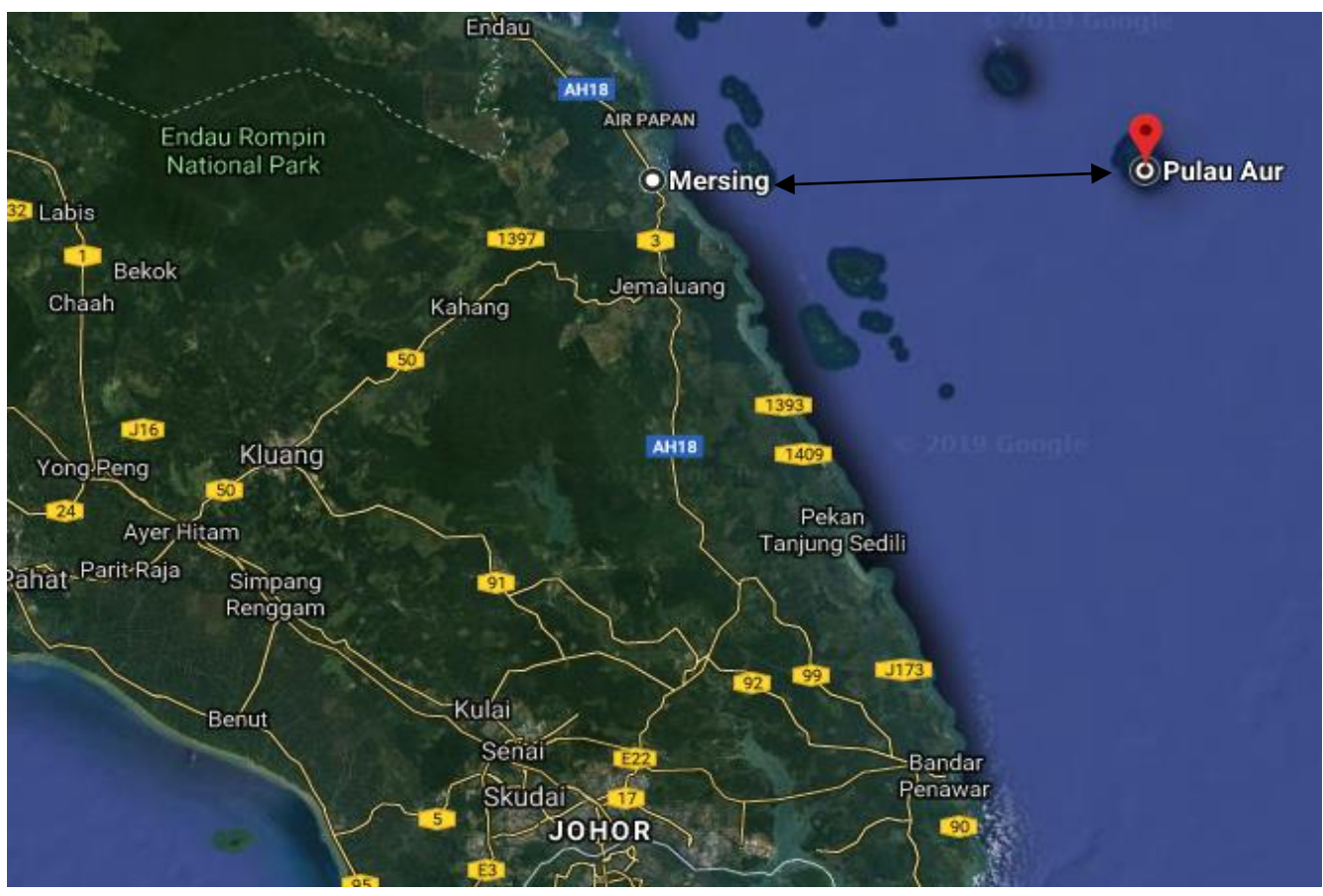

Figure 2. Location of the project site on a map

\section{DESIGN AND SYSTEM CONFIGURATION}

In RE project, a successful assessment requires pertinent criteria to be applied on the side data so that the operational behaviour of all possible cases can be properly analyzed. This includes the identification of system configuration which was in this case was designed based on the load consumption and other requirements from the project owner, the specification on the load demand, solar radiation, and temperature.

The collected data from site was illustrated and investigated. Each were discussed and analysed to describe the entire system.

\subsection{Load consumption}

A load consumption survey was roughly conducted during the site visit and the load type from each building was identified. There were several assumptions made during this activity due to time and information constraints.

According to the collected data as shown in the Table 3, the total daily load consumed by the whole village is 154.268 $\mathrm{kWh}$ /day. Figure 3 illustrates the load profile of the village; the average daily load is formed as peak demand which regulates the size of the system [37]. 
Table 3. Daily energy consumption from each building

\begin{tabular}{c|c|c|c|c}
\hline No & $\begin{array}{c}\text { Building } \\
\text { type }\end{array}$ & Unit & $\begin{array}{c}\text { Daily } \\
\text { Consumption } \\
\text { (kWh) }\end{array}$ & $\begin{array}{c}\text { Total Daily } \\
\text { Consumption } \\
\text { (kWh) }\end{array}$ \\
\hline 1 & School & 1 & 33.445 & 33.445 \\
\hline 2 & House & 16 & 5.204 & 83.264 \\
\hline 3 & Mosque & 1 & 7.603 & 7.603 \\
\hline 4 & $\begin{array}{c}\text { Village } \\
\text { Hall }\end{array}$ & 1 & 3.318 & 3.318 \\
\hline 5 & Police Hut & 1 & 22.551 & 22.551 \\
\hline 6 & Clinic & 1 & 4.087 & 4.087 \\
\hline $\begin{array}{c}\text { Total village daily } \\
\text { energy } \\
\text { consumption } \\
\text { (kWh) }\end{array}$ & \multicolumn{4}{|}{$\mathbf{1 5 4 . 2 6 8}$} \\
\hline
\end{tabular}

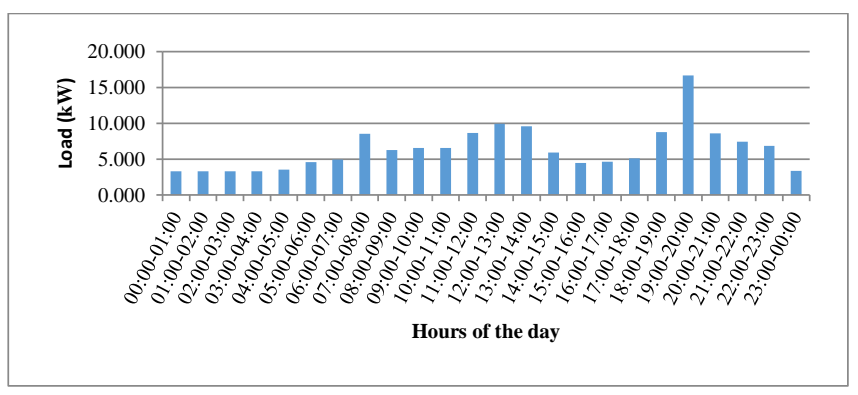

Figure 3. Daily load profile

The village load plotted in Figure 3 explains the pattern of power consumption in the whole village. Different from the typical patterns of village power consumption, this village's load profile consists of three peaks instead two. The peak at 0700-0800 marks the first peak of the day. This particular peak represents the period when most villagers prepare for their daily routines, including going to work, school and beach activities for tourists (if any). The power consumption during this hour is dominated by the usage of lamps, power points and kitchen utensils. The second peak occurred in between 12:0014:00. This particular peak represents loads consumed mainly from the school. As the temperature increases, airconditioning units and fans are switched on in buildings and houses during these hour. The last peak of the day is discovered at 19:00-20:00, during which most of the villagers return to their homes. At this period, the use of lamps, fans and kitchen utensils contribute to the power consumption. Home entertainment is also predicted to be running during these hours.

\subsection{Solar radiation}

Solar radiation obtained from NASA's database [38]. Figure 4 shows the monthly solar radiation data for the particular location which at generally in the range of 3.77-5.13 $\mathrm{kWh} / \mathrm{m}^{2} /$ day, with an annual average of $4.5 \mathrm{kWh} / \mathrm{m}^{2} /$ day and temperature is at $26.4^{\circ}$ at the average.

\subsection{System components}

The system was designed based on five (5) components integrated in forming a configuration that can work to supply the village load at the optimal level as depicted in Figure 5. Table 4 summarised each component selected for the system. A brief description on the calculation and parameters are presented as follows:

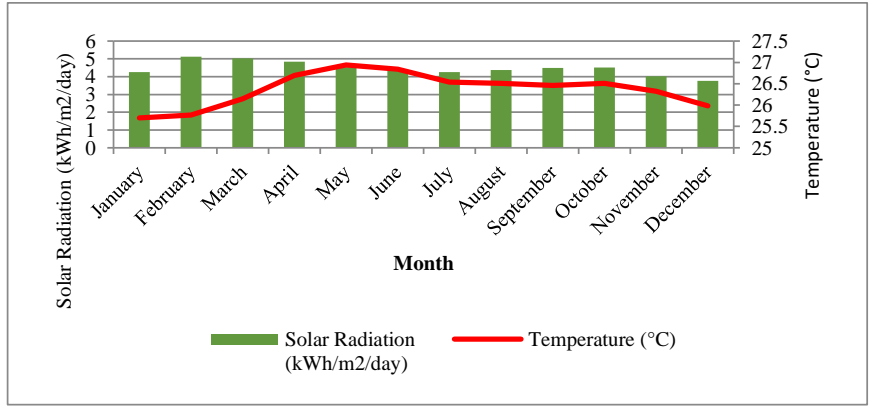

Figure 4. Solar radiation and temperature data taken from NASA's database

\subsubsection{PV array}

Solar energy is utilised as the base-load power source. PV array is dependent on the load consumption, solar radiation and renewable fraction. Renewable fraction is the certain fraction of the total energy delivered to the load that originated from the renewable power sources [39]. In this case, renewable power fraction can be determined based on the PV production. The sizing of the PV array capacity is calculated as following:

$$
\begin{gathered}
\mathrm{PV}_{\text {Array }}=\frac{\mathrm{PV}_{\text {frac }} \times \mathrm{L}_{D}}{\mathrm{P}_{s h} \times \eta_{P V}} \\
=\frac{70 \% \times 154.268}{4.5 \times 78.2 \%} \\
=30.6 \mathrm{kWp}
\end{gathered}
$$

PV array efficiency $\left(\eta_{P V}\right)$ is derived from estimated losses due to irradiances level, temperature, panel quality, panel array mismatch, ohmic wiring loss, inverter loss during operation [40].

\subsubsection{Bi-directional inverter}

A bi-directional inverter is set up to run the system by converting the direct current (DC) power produced from the PV array into alternating current (AC) power for load supply.

The inverse of the process, AC-DC conversion, is called rectification, which is required in battery charging. The inverter needs to be sufficiently extensive to cover the total energy consumed at one time, or generally known as the peak load $\left(\mathrm{L}_{P}\right)$ [41]. According to IEA, the sizing of the inverter shall be at least 3 times higher than the $\mathrm{L}_{P}$. In addition, a $10 \%$ extra power $\left(\mathrm{P}_{\text {ext }}\right)$ and $94 \%$ on the inverter efficiency $\left(\eta_{\text {inv }}\right)$ were considered. Given the calculation of the inverter capacity:

$$
\begin{gathered}
\mathrm{P}_{\text {inv }}=\mathrm{L}_{P} \times 3+\mathrm{P}_{\text {ext }} \\
=17 \mathrm{~kW} \times 3+5.1 \mathrm{~kW} \\
\frac{\eta_{\text {inv }}}{96 \%} \\
=58.5 \mathrm{~kW}
\end{gathered}
$$

A $60 \mathrm{~kW}$ bi-directional inverter (HPC-60) from Optimal Power Solutions (OPS) is used for this project. HPC-60 offers integrated power conversion and management solutions for off-grid applications.

\subsubsection{Solar Charge controller (MPPT Controller)}

Maximum Power Point Tracking (MPPT) controller functions to extract maximum power from the solar array and deliver it to the DC bus of the system. MPPT controller is a mandatory requirement if the solar PV is connected to the DC bus bar of the DC-coupled hybrid system. The primary 
function of this controller in the hybrid system is to regulate battery charging while protecting it from being overcharged by the solar PV, based on the system setpoints. MPPT capacity is determined by the size of PV array. As per calculated in Eq. (1), the compatible sizing for MPPT controller used for this project is at $45 \mathrm{~kW}$.

\subsubsection{Battery energy storage}

In HRES, battery is the component used for energy storage. The battery stores the excess energy produced by PV array during the daytime via the charging process. The stored energy is then utilised to power up the load demand whenever the supply is insufficient particularly during night time, cloudy or rainy days and this process is called battery discharging. The purpose of the battery is to control the mismatch between the load demand and electricity generation. The battery kWh is basically designed based on the energy consumption, Depth of Discharge (DOD) and autonomy. DOD limits the energy withdrawal from a battery set up at certain percentage before it gets re-charged while autonomy is defined as the reserved timing required for the battery system to undergo a back-up operation. It is determined in number of days.

$$
\text { Batt }_{k W h}=\frac{\mathrm{L}_{D} \times\left(\mathrm{n}+\mathrm{Batt}_{a u t}\right)}{\eta_{\text {batt }} \times D O D}
$$

In this case, the battery chosen is FIAMM LM1500 (12OPsz $1500)$. It is a 2 -volt deep cycle battery rated at $1500 \mathrm{Ah}$. A string of 120 unit batteries connected in parallel form a $360 \mathrm{kWh}$ of battery capacity operating at $240 \mathrm{~V}$.

\subsubsection{Diesel generator}

Diesel Generator (DG) is normally deployed to meet the peak demand typically when then there is no output from the PV array [42]. In this case, DG was meant to cater $30 \%$ of the total consumption on the daily basis. This system comes with a Cummins $62.5 \mathrm{kVA}$ from B3.3. It is a three-phase generator rated with 0.8 power factor, thereby giving the system an output power of $50 \mathrm{~kW}$. Operating in parallel setup with the existing DG from Gesan, the DGs shall operate as a source of supply during the shortfall of power from Solar PV and battery storage as well to periodically charge the battery to maintain it in a good condition. DG is characterised by its fuel consumption and efficiency. In such rural area, fuel price could be more expensive, at about 1.5 times the normal price due to the high cost of fuel transportation and storage constraints [43].

Table 4. Summary of the proposed equipment

\begin{tabular}{|c|c|c|c|c|}
\hline Component & $\begin{array}{c}\text { Unit } \\
\text { Capacity }\end{array}$ & Quantity & $\begin{array}{c}\text { Total } \\
\text { Capacity }\end{array}$ & Brand \\
\hline PV & $255 \mathrm{~W}$ & 120 & $30,600 \mathrm{~W}$ & Trinasolar \\
\hline Battery & $3000 \mathrm{~W}$ & 120 & $\begin{array}{c}360,000 \\
W\end{array}$ & FIAMM \\
\hline DG 1 & $60.2 \mathrm{kVA}$ & 1 & $60.2 \mathrm{kVA}$ & Cummins \\
\hline DG 2 & $60 \mathrm{kVA}$ & 1 & $60 \mathrm{kVA}$ & Gesan \\
\hline $\begin{array}{c}\text { Inverter } \\
\text { (HPC) }\end{array}$ & $60 \mathrm{~kW}$ & 1 & $60 \mathrm{~kW}$ & OPS \\
\hline MPPT & $45 \mathrm{~kW}$ & 1 & $45 \mathrm{~kW}$ & OPS \\
\hline
\end{tabular}

Figure 5 illustrates the overall configuration of the system with the capacity of the each equipment. Briefly explanation on how the system works is when at normal operating condition, when sun is available; energy generated by the PV array will be the highest priority to supply the loads. Meanwhile, in the event of excess energy produced from the PV array, it will then be used to charge the battery until it is fully charged. In case of insufficient energy produced by the PV system, the battery will be called and discharge the loads until it reaches the minimum level of state of State of Charge (SOC), then DG will start to supply the current load demand.

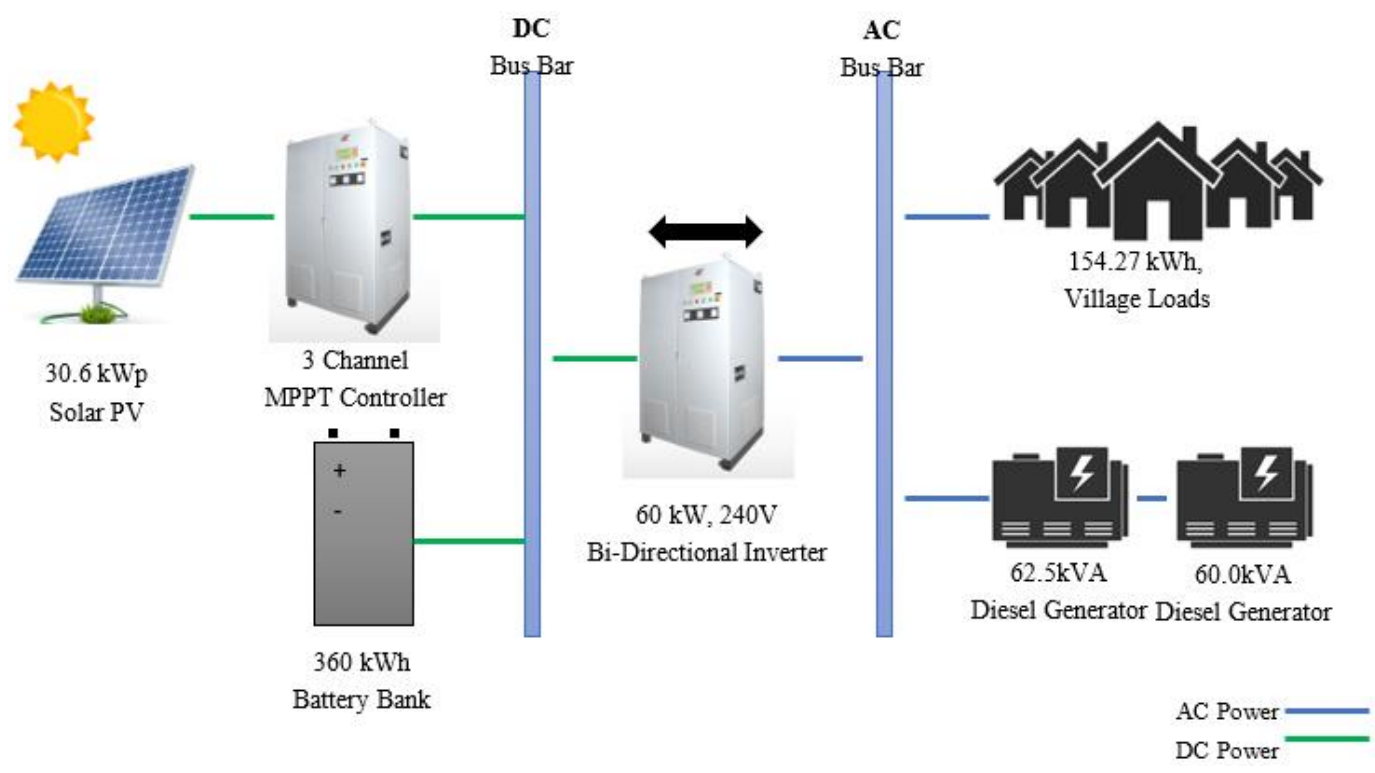

Figure 5. Overall system configuration comprised by the 5 discussed components

\section{RESULT AND DISCUSSION}

In this section, the result of system design feasibility, optimisation, and performance were presented and discussed. The discussion involves the simulation results of technical, economical and environmental analysis for different configurations including the proposed system design of hybrid PV-diesel-battery, existing stand-alone DG, and hypothetical a dual DGs system consists of an additional DG connected to the existing stand-alone DG system. Hybrid Optimisation 
Model for Electric Renewable, pro Edition (HOMER Pro®) has been extensively used in the simulation [44]. Table 5 shows the parameter and inputs used in the simulation.

Table 5. Technical parameters for system components

\begin{tabular}{c|c|c}
\hline Component & Factor & Value \\
\hline \multirow{4}{*}{ PV } & Rated power $(\mathrm{kWp})$ & 30.6 \\
\cline { 2 - 3 } & Temperature co-efficient $\left({ }^{\circ} \mathrm{C}\right)$ & -0.410 \\
\cline { 2 - 3 } & Derating factor $(\%)$ & 90 \\
\cline { 2 - 3 } & Operation temperature $\left({ }^{\circ} \mathrm{C}\right)$ & 44 \\
\cline { 2 - 3 } & Lifetime $($ Years) & 25 \\
\cline { 2 - 3 } & Efficiency (\%) & 16.2 \\
\hline \multirow{4}{*}{ Battery } & Nominal capacity (Ah/cell) & 1500 \\
\cline { 2 - 3 } & Nominal capacity (kWh/cell) & 3 \\
\cline { 2 - 3 } & Nominal Voltage (V/cell) & 2 \\
\cline { 2 - 3 } & Lifetime (Years) & 5 \\
\cline { 2 - 3 } & Roundtrip efficiency (\%) & 85 \\
\hline Inverter & Rated power (kW) & 60 \\
\hline & Lifetime (Years) & 25 \\
\hline & Rectifier efficiency (\%) & 96 \\
\hline & Inverter efficiency (\%) & 96 \\
\hline DGs & Rated power (kVA) & $62.5,60$ \\
\hline & Load minimum ratio (\%) & 30 \\
\hline
\end{tabular}

The feasibility of the modelled system is justified by HOMER Pro ${ }^{\circledR}$ and the system architecture implemented is as shown in Figure 6.

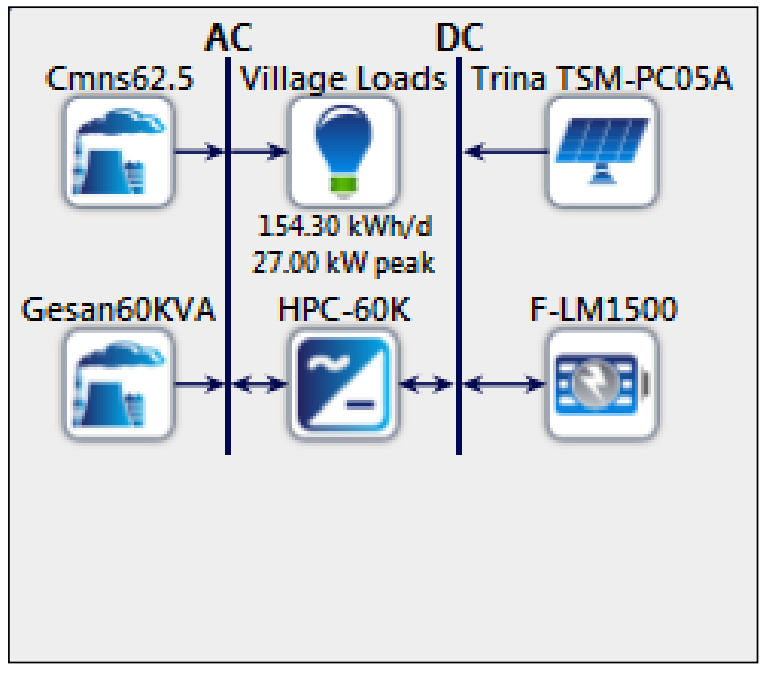

Figure 6. Proposed hybrid system design implemented in HOMER Pro®

\subsection{System configurations analysis}

System operation behaviour is presented for the 3 different configurations in the sub sections.

\subsubsection{Proposed hybrid PV-diesel-battery system}

The first configuration represents the proposed system configuration which was designed based on the village load profile and available resources. This system design is developed to reduce the dependency on the existing DG system and is designed to cater $70 \%$ of the total daily loads to be supplied by the renewable source in this case solar PV with battery bank integration for energy storage. From the simulation output, this configuration does provide the best economical system and performed better in technical, operation and environment aspects. In this case, PV produces about $69.2 \%$ of total electrical production making it the main source of supply for the system; meanwhile the two DGs operate to fulfil the demand whenever required. The new additional Cummins 62.5kVA DG produces $26.0 \%$, while the existing Gesan $60.0 \mathrm{kVA}$ DG produces $4.8 \%$ of the total yearly production. The configuration presents the lowest LCOE among other two at about RM 2.48/kWh with Net Present Cost (NPC) is RM 2,198,592 and operating cost is at RM 99,137.86. The system's initial capital, replacement and maintenance cost over the project period are RM 636,870.00, RM 916,942.47 and RM 299, 509.77 respectively. $65.2 \%$ of renewable fraction with $0.4 \%$ of excess energy was identified from HOMER Pro ${ }^{\circledR}$ analysis.

\subsubsection{Existing standalone diesel system (baseline} configuration)

The second configuration represents the existing system which has been the power source for the loads since a part of the system (solar PV side) is not longer functions. A Gesan $60.0 \mathrm{kVA}$ DG was solely producing energy for the whole village. This baseline analysis is crucial in quantifying the impact of integrating the existing with the PV system. In this case, where $100 \%$ production was made available by a DG had consumed about $29,383 \mathrm{~L}$ of diesel in a year and with the fuel cost of RM5/L estimated at rural rate, the LCOE for this baseline model is RM3.05/kWh and NPC is RM 2,704,717 which recorded as the highest cost of energy compared to other configurations. The system's initial capital, replacement and maintenance cost over the project period are RM 55,000, RM 176,963.32 and RM 161,558.58 respectively. The system capital for this case is allocated to only for minor refurbishment on the existing and mechanical work at the power station.

\subsubsection{Standalone dual diesel system (hypothetical model)}

In other case, where hypothetically a set of dual DG was considered, the existing Gesan 60kVA is set up to run along with the additional new $62.5 \mathrm{kVA}$ Cummins DG. This case was initiated mainly to avoid huge investment, long project implementation period and as a preparation for load growth. Furthermore, the existing DG is not in a good condition, agewise and it only scheduled to run at certain times of the day and years. The LCOE for this case found at RM2.97, slightly cheaper than the baseline configuration and NPC is RM 2,637,515.00. The system's initial capital, replacement and maintenance cost over the project period are RM 75,000, RM $176,963.32$ and RM 161,558.58 respectively.

\subsection{PV output and fuel summary}

The rated PV array capacity is at $30.6 \mathrm{~kW}$ with the capacity factor of $16.2 \%$ produces approximately $188 \mathrm{~kW}$ of energy on one sunny day. Its minimum output is found at $0 \mathrm{~kW}$, which certainly occurs during nigh time or rainy days, while the maximum output is calculated at $25.5 \mathrm{~kW}$. HOMER Pro ${ }^{\circledR}$ considers $12 \mathrm{~h}$ of operation for the PV per day. The operational behaviour of each system is tabulated in Table 6 and Figure 7 represents the electrical production. The PV output power is available from 7 am to $6 \mathrm{pm}$ to power up the load demand. The excess power generated by the PV is also simulated for use in battery charging. Figure 8 summarises the daily PV output power provided by HOMER Pro ${ }^{\circledR}$. 
Outside of these hours when the PV output is not available, the load demand will be fed by either the stored energy from the battery $(\mathrm{kWh})$ or the fuel from the DG. HOMER Pro ${ }^{\circledR}$ calculates the total yearly fuel consumed for this system at $4,455 \mathrm{~L}$. The average daily consumption is $12.2 \mathrm{~L} / \mathrm{day}$. The DG only operates to power up the load when the PV output is $0 \mathrm{~kW}$ and the battery lacks sufficient stored energy for discharge. The dispatch strategy set for this system is the load following (LF) strategy, in which an operating generator only produces enough power to meet the primary load. Lowpriority objectives, such as charging the storage bank or serving the deferrable load, are left to the renewable power sources [45]. However, as stated earlier in this article, the battery will be periodically charged by the DG to maintain the good conditions and this event is scheduled limited to certain times.

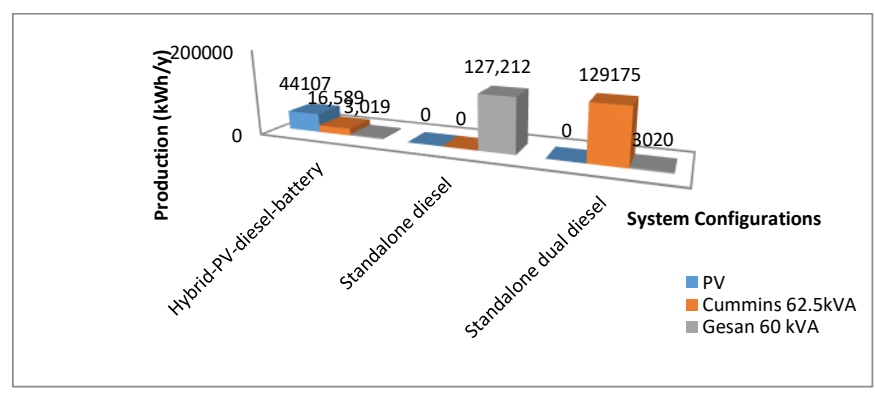

Figure 7. The electrical production from each system

Table 6. System operational behaviour

\begin{tabular}{c|c|c|c|c}
\hline System & Rated capacity (kW) & Production (\%) & Running Hours (h) & $\begin{array}{c}\text { Fuel Consumption } \\
(\mathbf{L} / \mathbf{y r})\end{array}$ \\
\hline \multicolumn{5}{c}{ Hybrid PV-diesel-battery system } \\
\hline PV & 30.6 & 69.2 & - & - \\
\hline DG 1 & 50 & 26.0 & 1,100 & 3,764 \\
\hline DG 2 & 48 & 4.8 & 204 & 691 \\
\hline Total & 128.6 & 100 & 1,304 & 4,455 \\
\hline \multicolumn{5}{c}{ Standalone diesel system } \\
\hline DG 2 & 48 & 100 & 8,760 & 29,383 \\
\hline Total & 48 & 100 & 8,760 & 29,383 \\
\hline \multicolumn{5}{|c|}{ Standalone dual diesel system } \\
\hline DG 1 & 50 & 97.7 & 8,556 & 29,294 \\
\hline DG 2 & 48 & 2.3 & 204 & 691 \\
\hline Total & 98 & 100 & 8,760 & 29,985 \\
\hline
\end{tabular}

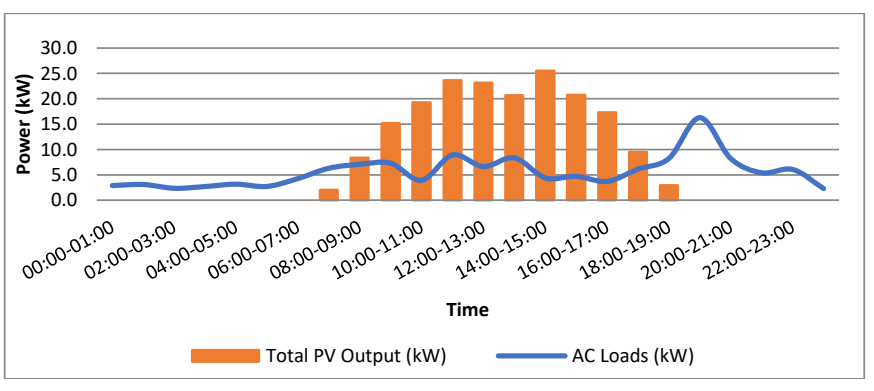

Figure 8. Daily PV kW output plotted against AC load served

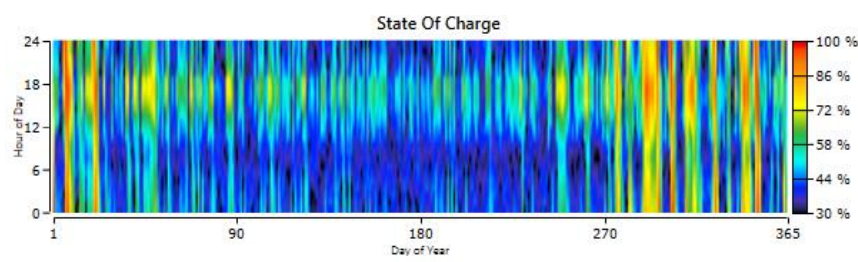

(a)

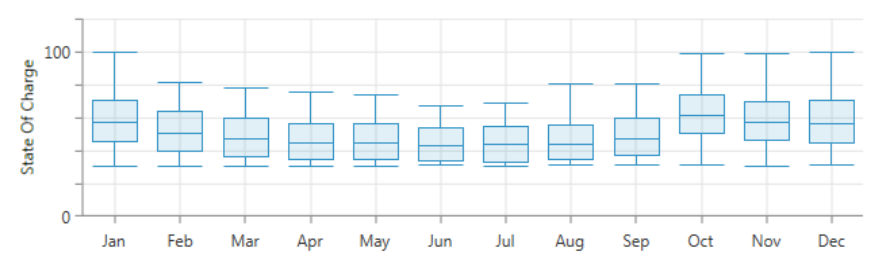

(b)

Figure 9. (a) Hourly SOC in a year (b) Monthly SOC in a year

\subsection{Battery storage system}

Battery plays a crucial role in HRES as it is used to store the generated energy from solar array and delivers it to load. It is usually charged at day time and energy is withdrawn in the evening, around sunset where the loads spike. This system demonstrates the need of including batteries to store excess energy from the PV. The appearance of the batteries enhances the system performance as the ones without storage have enduring a substantial amount of excess energy; such in this case the excess energy coming from the two DGs.

The battery yearly SOC analysis for the system is shown in Figure 9.

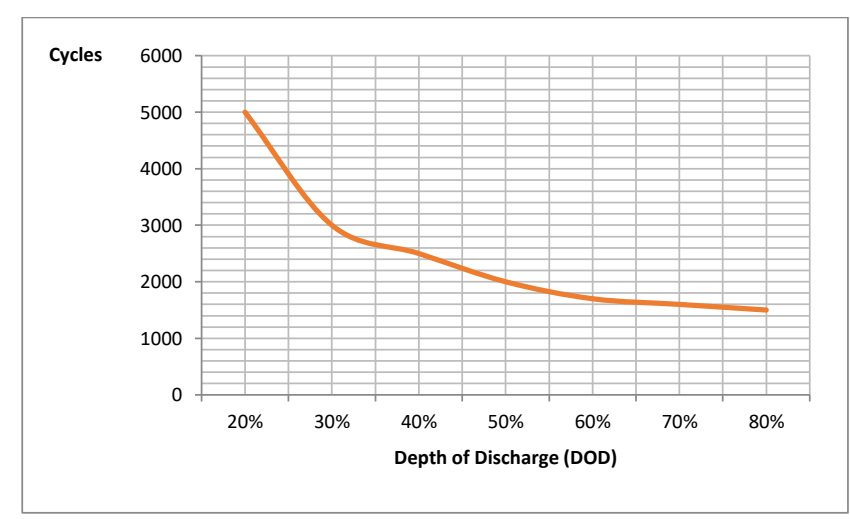

Figure 10. Cycle to failure curve of the battery

The estimated lifetime of each battery included in HOMER Pro ${ }^{\circledR}$ input parameter was based on the cycles curve obtained from manufacturer. Considering each battery operate in one 
cycle per day, at 70\% DOD it would have about 1600 cycles before failure and from HOMER Pro ${ }^{\circledR}$ result, the battery life time is found be about 5 years. Figure 10 explains the cycle to failure of the battery.

The storage system is very important in ensuring the stability of the system as it will prevent the excess and losses energy which could affect the system operation.

\subsection{System operational analysis}

In this section, the daily Battery plays a crucial role in system operation was analysed based on one random day with a normal condition picked up from the simulation result. The result captured from HOMER Pro ${ }^{\circledR}$ has justified that the system is feasible to run an average of $154.27 \mathrm{kWh}$ of village loads. The graph in Figure 11 explains the daily operation of the hybrid PV-diesel-battery system from the starting point of the day at midnight 00:00:00 where the loads are being powered up by the DG and the same time charging the depleted battery from the day before. This process remains until about 06:00:00 in the morning which when the DG is sent offline, leaving the battery to discharge its power and continue to supply the loads. At about 07:00:00 to 08:00:00, when there is a presence of solar radiation, PV system starts to operate supplying the loads along with the battery for about first 1 to 2 hours before it manages to produce sufficient power to supply the total loads as the sun goes up. In between these hours (08:00:00 - 18:00:00), loads are purely powered up by PV system which at the same time produces excess power for battery charging. The energy stored in the battery will be then used to power up loads during night time. Moving towards end of day time, as the PV output is getting lower, battery will start to discharge and assist to supply the loads until PV system is totally stop producing at about 07:00:00, leaving the battery to further discharge its power for the remaining loads until the next day. The controller manages the power movement to ensure that the supply is not interrupted [46].

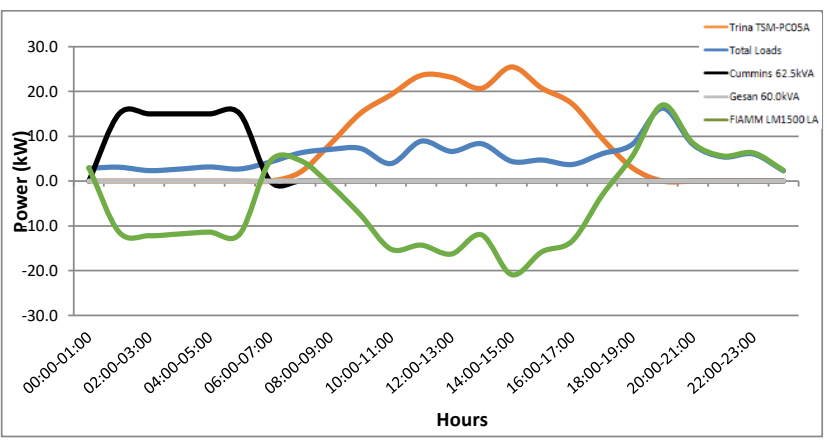

Figure 11. System daily operation analysed by HOMER Pro®

\subsection{Economic analysis}

Table 7 summarised the NPC, operating, LCOE and initial capital cost for each configuration. As reviewed, it shows that the hybrid PV-diesel-battery system provides the lowest NPC and LCOE, followed by the hypothetical case of dual diesel system and the standalone diesel system. The result gathered presented that hybrid PV-diesel-battery system offers the best economic properties over the project period.

Even though the hybrid-PV-diesel-battery started with a significant high initial capital, but its operational cost is lower than other two configurations due to the minimum involvement of DG resulted in lower fuel consumption.

Figure 12 shows the combination of all cost incurred for the three configurations. The major portion of the cost for hybrid PV-diesel-battery comes from the component replacements cost for instance battery system which needs to be replaced in every 5 years, while fuel cost dominating the cost for standalone diesel and dual diesel systems.

Table 7. Economic summary of different system configurations

\begin{tabular}{ccccc}
\hline System & NPC (RM) & Operational Cost (RM) & LCOE (RM) & Initial Capital (RM) \\
\hline Hybrid PV-diesel-battery & $2,198,529.00$ & $99,137.86$ & 2.48 & $636,870.00$ \\
\hline Standalone diesel & $2,704,717.00$ & $168,210.40$ & 3.05 & 55,000 \\
\hline Standalone dual diesel & $2,637,515.00$ & $162,674.60$ & 2.97 & 75,000 \\
\hline
\end{tabular}

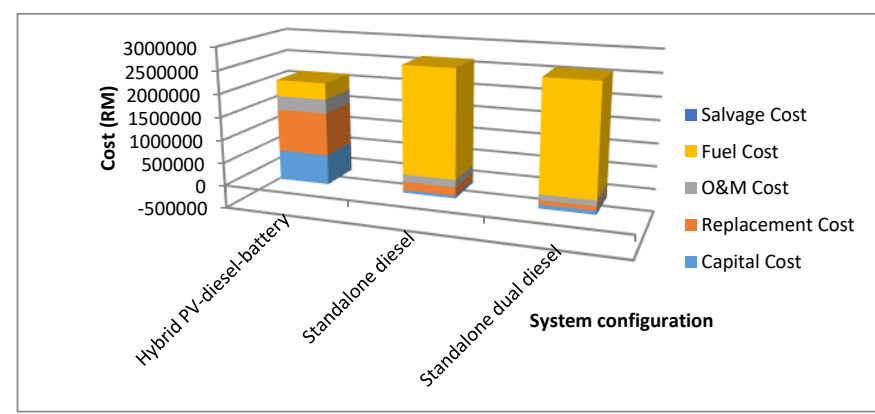

Figure 12. Cost analysis over all combinations

\subsection{Emission analysis}

The additional of PV to the standalone diesel system is significantly resulted in emission reduction. From these 3 system configurations, it is found that the reduction of carbon dioxide and carbon monoxide emission is at $85 \%$ can be secured by injecting the PV and battery elements in the existing system. This is mainly due to the limitation in diesel usage. The hybrid pv-diesel-battery is obviously the best system from an environmental standpoint, while the other two configurations which both are driven by DG regarded as the worst. The level of emission is shown in Figure 13.

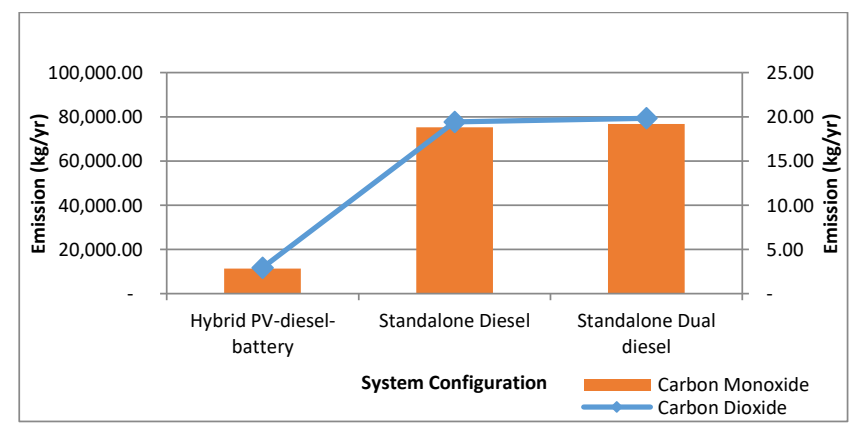

Figure 13. Emission from each system configuration 


\section{CONCLUSION}

The study aims to investigate the feasibility and the performance of the proposed system design for rural electrification at $\mathrm{Kg}$ Teluk Berhala, Aur Island Mersing, Malaysia. The proposed hybrid PV-diesel-battery system is found to be technically and economically feasible to supply an average of $154 \mathrm{kWh}$ of daily loads consumed by the village. HOMER Pro ${ }^{\circledR}$ has been extensively used in analysing the system performance where other two configurations were also considered for comparative analysis. The three configurations were:

$$
\begin{array}{ll}
\text { i. } & \text { Hybrid PV-diesel-battery system (proposed) } \\
\text { ii. } & \text { Standalone diesel system (existing) } \\
\text { iii. } & \text { Standalone dual diesel system (hypothetical) }
\end{array}
$$

The idea of having the proposed system compared to the existing system is to show the impact from RE integration into the standalone diesel system which provides huge reduction in diesel consumption at about $85 \%$. The hybrid system is designed to cater about $70 \%$ of the daily load consumptions supplied by the PV, while the remaining $30 \%$ supplied by the DG. This formation has been justified by HOMER Pro®, when it shows the RE fraction of the system is found to be about $65.2 \%$, considering all the losses in its calculation.

Financially, hybrid PV-diesel-battery provides the lowest NPC of RM 2,198,529.00 and LCOE at RM2.48. The reduction in the LCOE is calculated at about $19 \%$ and $16 \%$ against standalone diesel system and standalone dual diesel system respectively. This study has also presented the crucial role of battery storage system in storing excess energy and reducing losses.

The integration of PV and battery system in power generation has proven to be the best additional sources for rural electrification. However further studies considering sensitivity analysis and other aspects such as different configuration involving other RE sources are encouraged.

\section{ACKNOWLEDGMENT}

The authors would like to thank Optimal Power Solutions for the helpful assistance and guidance.

\section{REFERENCES}

[1] US Energy Information Administration (UIA). (2019). International Energy Outlook 2019-ConsumptionEnglish Version. https://www.eia.gov/outlooks/ieo/pdf/ieo2019.pdf.

[2] Panos, E. Densing, M. Volkart, K. (2016). Access to electricity in the world Energy Council's global energy scenarios: An outlook for developing regions until 2030. Energy Strategy Reviews, 9: 28-49. https://doi.org/10.1016/j.esr.2015.11.003

[3] The Rockefeller Foundation, Eixabay. https://www.rockefellerfoundation.org/.

[4] International Energy Agency (IEA). (2017). World Energy Outlook 2017- Executive Summary - English version. https://www.iea.org/reports/world-energyoutlook-2017.

[5] 2019 Tracking Sustainable Development Goal (SDG 7):
The Energy Process Report Chapter I: Access to Electricity.

https://sustainabledevelopment.un.org/content/documen ts/2019_Tracking_SDG7_Report.pdf.

[6] More People Have Access to Electricity Than Ever Before, but World Is Falling Short of Sustainable Energy Goals. https://www.worldbank.org/en/news/pressrelease/2019/05/22/tracking-sdg7-the-energy-progressreport-2019.

[7] Cecelsky, E., Glatt, S. (1982). Development, energy in developing countries series, discussion paper D-73E, Resources for the Future. https://pdf.usaid.gov/pdf_docs/pnaaq579.pdf.

[8] Hirmer, S., Cruickshank, H. (2014). The user-value of rural electrification: an analysis and adoption of existing models and theories. Renewable and Sustainable Energy Reviews, 34: 145-154. https://doi.org/10.1016/j.rser.2014.03.005

[9] Zomers, A. (2003). The challenge of rural electrification. Energy for Sustainable Development, 7(1): 69-76. https://doi.org/10.1016/S0973-0826(08)60349-X

[10] Odai, O.D.T., Bhandari, R., Adamou, R. (2019). Technoeconomic data for decentralised energy system sizing for rural areas in Benin. A case study of the village of Fouay. Data in Brief, 26: 104501. https://doi.org/10.1016/j.dib.2019.104501

[11] Krishan, O., Suhag, S. (2019). Techno-economics analysis of a hybrid renewable energy system for an energy poort rural community. Journal of Energy Storage, 23: 365-319. https://doi.org/10.1016/j.est.2019.04.002

[12] Perera, A.T.D., Attalage, R.A., Perera, K.K.C.K., Dassanayake, V.P.C. (2013). Designing stand-alone hybrid energy systems minimising initial investment, life cycle cost and pollutant emission. Energy, 54: 220-230. https://doi.org/10.1016/j.energy.2013.03.028

[13] Shah, K.K., Mundada, A.S., Pearce, J.M. (2015). Performance of U.S hybrid distributed energy system. Solar photovoltaic, battery and combined heat and power. Energy Conversion and Management, 105: 71-80.

[14] Yang, H., Zhou, W., Lou, C.Z. (2009). Optimal design and techno-economic analysis of a hybrid solar-wind power generation system. Applied Energy, 86(2): 163169. https://doi.org/10.1016/j.apenergy.2008.03.008

[15] Phuangpornpitak, N., Kumar, S. (2007). PV hybrid systems for rural electrification in Thailand. Renewable and Sustainable Energy Reviews, 11(7): 1530-1543. https://doi.org/10.1016/j.rser.2005.11.008

[16] Olatomiwa, L., Mekhilef, S., Huda, A., Sanusi, K. (2015). Techno-economic analysis of hybrid PV-diesel-battery and PV-wind-diesel-battery power systems for mobile BTS: The way forward for rural development. Energy Sci Eng., 3(4): 271-285. https://doi.org/10.1002/ese3.71

[17] World Bank. (2017). State of electricity access report (SEAR).

http://documents.worldbank.org/curated/en/3645714945 17675149/pdf/114841-REVISED-JUNE12-FINALSEAR-web-REV-optimized.pdf.

[18] Wong, S.Y., Chai, A. (2012). An off-grid solar system for rural village in Malaysia. In: 2012 Asia-Pacific Power and Energy Engineering Conference. https://doi.org/10.1109/APPEEC.2012.6307162

[19] Ajan, C.W., Ahmed, S.S., Ahmad, H.B., Taha, F., Zin, A.A.B.M. (2003). On the policy of photovoltaic and diesel generation mix for an off-grid site: East Malaysian 
perspectives. Solar Energy, 74(6): 453-467. https://doi.org/10.1016/S0038-092X(03)00228-7

[20] Khatib, T., Mohamed, A., Sopian, K., Mahmoud, M. (2011). Optimal sizing of building integrated hybrid PV/diesel generator system for zero load rejection for Malaysia. Energy and Buildings, 43(12): 3430-3435. https://doi.org/10.1016/j.enbuild.2011.09.008

[21] Neves, D., Silva, C.A., Connors, S. (2014). Design and implementation of hybrid renewable energy systems on micro-communities: A review on case studies. Renew Sustain Energy Reviews, 31: 935-946. https://doi.org/10.1016/j.rser.2013.12.047

[22] Olatomiwa, L., Mekhilef, S., Ohunakin, O.S. (2016). Hybrid renewable power supply for rural health clinics (RHC) in six geo-political zones of Nigeria. Sustain Energy Technol Assess., 13: 1-12. https://doi.org/10.1016/j.seta.2015.11.001

[23] Banos, R., Manzano-Agugliaro, F., Montoya, F., Gil, C., Alcayde, A., Gómez, J. (2011). Optimization methods applied to renewable and sustainable energy: A review. Renew Sustain Energy Rev., 15(4): 1753-1766. https://doi.org/10.1016/j.rser.2010.12.008

[24] Belfkira, R., Zhang, L., Barakat, G. (2011). Optimal sizing study of hybrid wind/PV/diesel power generation unit. Sol Energy, 85(1): 100-110. https://doi.org/10.1016/j.solener.2010.10.018

[25] Erdinc, O., Uzunoglu, M. (2012). Optimum design of hybrid renewable energy systems: Overview of different approaches. Renew Sustain Energy Rev., 16(3): 14121425. https://doi.org/10.1016/j.rser.2011.11.011

[26] Haidar, A.M., John, P.N., Shawal, M. (2011). Optimal configuration assessment of renewable energy in Malaysia. Renew Energy, 36(2): 881-888. https://doi.org/10.1016/j.renene.2010.07.024

[27] Zahboune, H., Zouggar, S., Krajacic, G., Varbanov, P.S., Elhafyani, M., Ziani, E. (2016). Optimal hybrid renewable energy design in autonomous system using Modified Electric System Cascade Analysis and Homer software. Energy Convers Manage, 126: 909-922. https://doi.org/10.1016/j.enconman.2016.08.061

[28] Olatomiwa, L., Mekhilef, S., Ismail, M., Moghavvemi, M. (2016). Energy management strategies in hybrid renewable energy systems: A review. Renew Sustain Energy Rev., 62: 821-835. https://doi.org/10.1016/j.rser.2016.05.040

[29] Mahmoud, M.M., Ibrik, I.H. (2006). Techno-economic feasibility of energy supply of remote villages in Palestine by PV-systems, diesel generators and electric grid. Renew Sustain Energy Rev., 10: 128-138. https://doi.org/10.1016/j.rser.2004.09.001

[30] Karakoulidis, K., Mavridis, K., Bandekas, D., Adoniadis, P., Potolias, C., Vordos, N. (2011). Techno-economic analysis of a stand-alone hybrid photovoltaic-dieselbattery-fuel cell power system. Renew Energy, 36(8): 2238-2244. https://doi.org/10.1016/j.renene.2010.12.003

[31] Rajkumar, R., Ramachandaramurthy, V., Yong, B., Chia, D. (2011). Techno-economical optimization of hybrid pv/wind/battery system using Neuro-Fuzzy. Energy, 36(8): 5148-5153.

[32] Saheb-Koussa, D., Haddadi, M., Belhamel, M. (2009). Economic and technical study of a hybrid system (wind - photovoltaic-diesel) for rural electrification in
Algeria. Appl Energy, 86(7-8): 1024-1030. https://doi.org/10.1016/j.apenergy.2008.10.015

[33] Ohijeagbon, O., Ajayi, O.O. (2015). Solar regime and LVOE of PV embedded generation systems in Nigeria. Renew Energy, 78: 226-235. https://doi.org/10.1016/j.renene.2015.01.014

[34] Baneshi, M., Hadianfard, F. (2016). Techno-economic feasibility of hybrid diesel/PV/ wind/battery electricity generation systems for non-residential large electricity consumers under southern Iran climate conditions. Energy Convers Manage., 127: 233-244. https://doi.org/10.1016/j.enconman.2016.09.008

[35] Rehman, S., Al-Hadhrami, L.M. (2010). Study of a solar PV-diesel-battery hybrid power system for a remotely located population near Rafha, Saudi Arabia. Energy Dec., 35(12): 4986-4995. https://doi.org/10.1016/j.energy.2010.08.025

[36] Cader, C., Bertheau, P., Blechinger, P., Huyskens, H., Breyer, C. (2016). Global cost advantages of autonomous solar - battery - diesel systems compared to diesel only systems. Energy Sustain Develop., 31: 14-23. https://doi.org/10.1016/j.esd.2015.12.007

[37] Khulna, T. (2015). Grid connected hybrid power system design using HOMER. 2015 International Conference on Advances in Electrical Engineering (ICAEE), pp. 19-22. https://doi.org/10.1109/ICAEE.2015.7506786

[38] NASA. Surface meteorology and solar energy. https://power.larc.nasa.gov/.

[39] Ramli, M.A.M., Hiendro, A., Bouchekara, H.R.E.H. (2014). Performance analysis of hybrid PV/diesel energy system in western region of Saudi Arabia. International Journal of Photoenergy, 2014: 626251. https://doi.org/10.1155/2014/626251

[40] Ria, Sudhakar, K., \& Samykano, M. (2018). Performance of utility scale PV plant in Malaysia and India: A comparative study. 2018 4th International Conference on Electrical Energy Systems (ICEES). https://doi.org/10.1109/ICEES.2018.8442361

[41] Mitscher, M., Ruther, R. (2012). Economic performance and policies for grid-connected residential solar Photovoltaic systems in Brazil. Energy Policy, 49: 688694. https://doi.org/10.1016/j.enpol.2012.07.009

[42] Nfah, E., Ngundam, J. (2008). Modelling of wind/Diesel/battery hybrid power systems for far North Cameroon. Energy Convers Manage, 49(6): 1295-1301. https://doi.org/10.1016/j.enconman.2008.01.007

[43] Anwari, M., Rashid, M., Muhyiddin, H., Ali, A. (2012). An evaluation of hybrid wind/diesel energy potential in Pemanggil Island Malaysia. In: International Conference on Power Engineering and Renewable Energy (ICPERE), pp. 1-5. https://doi.org/10.1109/ICPERE.2012.6287244

[44] Lambert, T., Gilman, P., Lilienthal, P. (2006). Micropower system modeling with HOMER. Integr Altern Sources Energy, 1: 379-418.

[45] https://www.homerenergy.com/products/pro/docs/latest/ load_following_strategy.html.

[46] Halim, A., Fudholi, A., Sopian, K., Ruslan, M.H., Phillips, S.J. (2018). Feasibility study on hybrid solar photovoltaic with diesel generator and battery storage design and sizing using homer Pro ${ }^{\circledR}$. Journal of Engineering, $\quad 1(3)$ : 69-76. http://dx.doi.org/10.17576/jkukm-2018-si1(3)-10 


\section{NOMENCLATURE}

LCOE

$\mathrm{PV}_{\text {frac }}$

$\mathrm{L}_{D}$

$\mathrm{P}_{s h}$

$\eta_{P V}$

DC

AC

$\mathrm{L}_{P}$
Levelised Cost of Energy

PV Fraction

Load Demand

Peak Sun Hour

PV efficiency

Direct Current

Alternating Current

Peak Load
$\mathrm{P}_{\text {ext }}$

$\eta_{\text {inv }}$

$\mathrm{P}_{i n v}$

DOD

Battery $k w h$

$\eta_{\text {batt }}$

Batt $_{\text {aut }}$

$\mathrm{SOC}$

NPC
Extra Power

Inverter efficiency

Inverter Power

Battery depth of discharge

Battery energy

Battery efficiency

Battery Autonomy

Battery state of charge

Net Present Cost 